\title{
INFLUENCE OF SOCIAL INTERACTION IN A GROUP ON YOUNG GIRLS' PHYSICAL PERFORMANCE
}

\author{
Kateřina STRAŠILOVÁ ${ }^{1} \&$ Petr VAJDA ${ }^{1}$ \\ ${ }^{1}$ Masaryk University, Faculty of Sport Studies, Brno, Czech Republic \\ Corresponding Author: \\ Kateřina STRAŠILOVÁ, MSc \\ Masaryk University, Faculty of Sport Studies, Kamenice 5, 62500 Brno, Czech Republic \\ Phone: 420549492000 \\ e-mail: katka.strasilova24@gmail.com
}

\section{ABSTRACT}

It is assumed that there are many factors influencing sport performance in youth sport. This research is designed to find out whether there are any differences between individual and group physical performance. The aim of study is to report on the effect of social-comparative effect on young girls'physical performance. The study involved young elite synchronized swimmers from a Czech club with Olympic tradition who compete at an international level $(n=28$, age 10.12 1.20$)$. The swimmers were required to hold a wall-seat position as long as possible in two separately measured rounds, i.e. as individuals and as a group. The girls were randomly split into two groups. They started with an individual or group try of the wall-seat position exercise. There was a week's interval between the measured rounds. The mean performance was $M=108.82 \pm 57.10$ in the individual try and $M=271.50 \pm 218.88$ in the group one. The influence of social interaction in the group was evaluated by Cohen's $d$ which showed high substantive differences ( $d=1.1$, large effect). The Wilcoxon matched pair test was used for data analysis (results were statistically significant, $P<0.05$ ). It showed mutual social encouragement in a group that caused improvement in performing a wall-seat position and influenced significantly their performance. However, it was also established that such social interaction / encouragement is not consistent for every child. Nevertheless, there are many other important factors influencing a youth physical performance as positive verbal motivation, constructive feedback or appraisal.

Keywords: group cohesion, mutual encouragement, self-motivation, sport performance, synchronized swimming, youth athletes. 


\section{VPLIV SOCIALNIH INTERAKCIJ V SKUPINI NA TELESNE ZMOGLJIVOSTI DEKLIC}

\section{IZVLE $\check{C} E K$}

Na uspešnost udejstvovanja v mladinskem športu vplivajo številni dejavniki. Namen pričujoče raziskave je bil ugotoviti morebitne razlike med telesnimi zmogljivostmi pri individualnem in skupinskem udejstvovanju. V raziskavo smo vključili skupino mladih vrhunskih športnic skladnostnega plavanja iz češkega kluba z olimpijsko tradicijo, ki tekmujejo na mednarodnem nivoju (n=28, starost 10,12 1,20). Plavalke smo prosili, da vztrajajo v položaju »sedenje ob steni« kolikor mogoče dolgo. Vajo smo ponovili dvakrat, $s$ to razliko, da so jo udeleženke v raziskavi enkrat izvajale individualno, nato pa še skupinsko. Dekleta smo naključno razdelili $v$ dve skupini in pri eni smo najprej merili individualno izvedbo, pri drugi pa skupinsko izvedbo vaje. Interval med enim in drugim merjenjem je bil en teden. Povprečni izmerjeni dosežki udeleženk v raziskavi so bili $M=108.82 \pm 57.10$ pri individualni izvedbi vaje in $M=271.50 \pm 218.88$ pri skupinski. Učinek socialne interakcije v skupini smo ovrednotili s pomočjo Cohenovega d indeksa, ki je pokazal visoko statistično odstopanje ( $d=1,1$, velik učinek). Za analizo podatkov smo uporabili Wilcoxonov test predznačenih rangov (rezultati so bili statistično pomembni, $P<0,05)$. Izkazalo se je, da je vzajemna socialna vzpodbuda v skupini povzročila učinkovitejše izvajanje vaje sedenja ob steni in znatno vplivala na izmerjene rezultate. Tekom raziskave pa smo ugotovili tudi, da tovrstna socialna interakcija/ vzpodbuda ne vpliva nujno na vsakega otroka. Vsekakor obstaja še vrsta drugih pomembnih faktorjev, ki vplivajo na otrokovo samomotivacijo kot npr. pozitivno verbalno motiviranje, konstruktivne povratne informacije in pohvale.

Ključne besede: skupinska kohezivnost, vzajemno vzpodbujanje, samomotivacija, športna zmogljivost, skladnostno plavanje, mlade športnice

\section{INTRODUCTION}

Motivation to exercise, often referred to as a need of achievement, is described as a need to prove something difficult, be the best, overcome yourself and your rivals. The natural social aspect of motivation to exercise is an effort to compete with others (Výrost \& Slaměník, 2008).

Similarly, Heckhausen (1991) described the need to be the best or to do things better than before or to do them better than other people. Motivation to exercise is proposed by many psychological factors. Enjoyment, social influence and self-efficacy are among the most frequently mentioned (Carron, Hausenblas, \& Mack, 1996; Irwin, Scorniaenchi, Kerr, Eisenmann, \& Feltz, 2012; Mcauley \& Courneya, 1993). Another 
factor that should not be overlooked is exercising in a group. The motivational effect of a group activity has been studied for many years, mainly in social psychology, and it was shown it could lead to higher exercise adherence than individual programs (Dishman \& Buckworth, 1996).

The motivational effect of exercising in a group was described in two different ways. The first one, the so-called motivational loss, is caused by a phenomenon of social lofting. Especially more capable team members developed less effort than if they worked individually (Baron \& Kerr, 2003). However, motivation gain is described more frequently. The Köhler motivation effect and social compensation are two phenomena which are connected with motivation gain. In case when superior group members work hard and increase their individual effort in order to compensate the effort of less-capable group members we call it social compensation (Osborn, Irwin, Skogsberg, \& Feltz, 2012). The Köhler effect occurs when the inferior group members enhance their effort to cooperate with the superior members (Baron \& Kerr, 2003). It was shown that the Kohler effect is task-dependent (Weber \& Hertel, 2007). For example, Steiner (1972) created the task taxonomy which divided motivation tasks into three relevant categories: conjunctive, coactive, and additive. The first one, the conjunctive task, means that group performance is dependent on the inferior members' performance. The result of the weakest member defined the overall team result. The second one, the coactive task, means that the task is performed simultaneously by all members of the group, but their individual result is not dependent on the outcome of other group members. The last one, the additive task, describes an exercise when the sum of members performance represents the result of the group. On the other hand, Kerr et al. (2007) proposed two main explanations of the Köhler effect. One explanation works with conjunctive theory. It says that group performance will always be as strong as the weakest group member. It brings motivation gain for the inferior group members who want to get closer to the stronger members because they know that the group result is dependent on their performance. The other explanation suggests an increase in motivation due to social comparison. It means that the presence of superior group members may enhance personal and performance goals of weaker group members.

It was shown from previous studies that the greatest motivation gains for the weakest group members was in a conjunctive group task, when the weaker members were exercising with moderate partners, it worked especially for women. On the other hand, it has been shown that a lot of men work better in coactive tasks with a superior coworker and it does not matter if they cooperate on a task or not (Weber \& Hertel, 2007). On the contrary, Feltz, Kerr and Irwin (2011) found out that the increase in motivation was entirely the result of social comparison. It means that the presence of the other group member brought the main motivation gain regardless if they work on the group goal or not. It was also confirmed that the motivation gains are greatest when the inferior members are 1.4 times weaker than the stronger ones (Messé, Hertel, Kerr, Lount Jr, \& Park, 2002). Nevertheless, the differences between the most and the least capable partners should not be too large as this can cause motivation losses (Hertel, Niemeyer, \& Clauss, 2008). 
Kateřina STRAŠILOVÁ, Petr VAJDA: INFLUENCE OF SOCIAL INTERACTION IN A GROUP ON YOUNG GIRLS' PHYSICAL ..., 3-13

Osborn et al. (2012) states that motivation is a cognitive process and it is impossible to express it in the correct way. For this reason, the motivation is inferred from the performance differences that could be weakness as well. Unfortunately, many previous studies have been done in laboratory conditions only and they have not been tested on real existing sports teams. It means that we have many results which demonstrated the effects of Kohler motivation gains but only a few of them aim to show effectiveness in real sport team groups.

\section{METHODS}

\section{Subject}

A number of thirty-three girls at the age ranging from eight to twelve $(M=10.12 \pm 1.20)$ were randomly split into two groups (fifteen and sixteen). The girls were young elite synchronized swimmers from the Czech club with Olympic tradition who compete at an international level. The experimental group consisted of two smaller training groups (younger and older ones). The girls are close friends within the training group, but they do not know well the girls from the other training group. The girls from both training groups were randomly split in two experimental groups. Their physical performance was measured in two separate rounds, i.e. as individuals and as a group. The first group started with individual exercises and the second one with exercising in a group. Though this approach we controlled the effect of previous experience with testing session. There was a one-week interval between the rounds. Five girls did not finish the research because of health reasons. Therefore, only twenty-eight girls fulfilled the whole protocol. It changed the number of participants in the examined groups to 13:15.

\section{Consent}

Before the beginning of this research, all under-aged girls' parents were thoroughly informed about the research purpose and all potential health and other risks. All parents agreed on their children's participation and signed appropriate consensus documents.

\section{Procedure}

All girls held a wall-seat position (isometric strength) as long as they were able to in two separate occasion. In the individual try, there was only the researcher and the tested girl, however, in the group test, there were all girls from the selected part of the sample. The group exercising was coactive, it means the girls exercised together in the same room and at the same time but we measured individual time of each girl, not a team result. Both measurements took place at the same time of a day with a one-week 
rest interval. All of the girls participated in both tests, in the individual as well as the group one, so we gathered the data to compare performance with or without the presence of teammates for each participant. In this way, we were able to measure the effect of the exercise on physical performance in a small social group. Performance duration was recorded for each occasion and later used to interpret the findings. The girls held a wall-seat position when they leaned their back against the wall with arms held forward. They bent the ankles, knees, and hips at the right angle. It looked as if they were sitting on an imaginary chair (fig. 1 and 2). All girls received the same instructions: "Girls, I would like you to hold the wall-seat position as long as you can. When it starts to hurt too much or you get too tired only then you can sit on the floor and leave the room. Do you understand what to do?" The subjects were not allowed to talk during the session and were informed about their results after their second measurement. When they did not abide by the instructions, during the exercise position, they were immediately asked to adjust it. If they did not adjust the position immediately, the exercise was stopped.

\section{Fig. 1 and 2: Wall seat position}
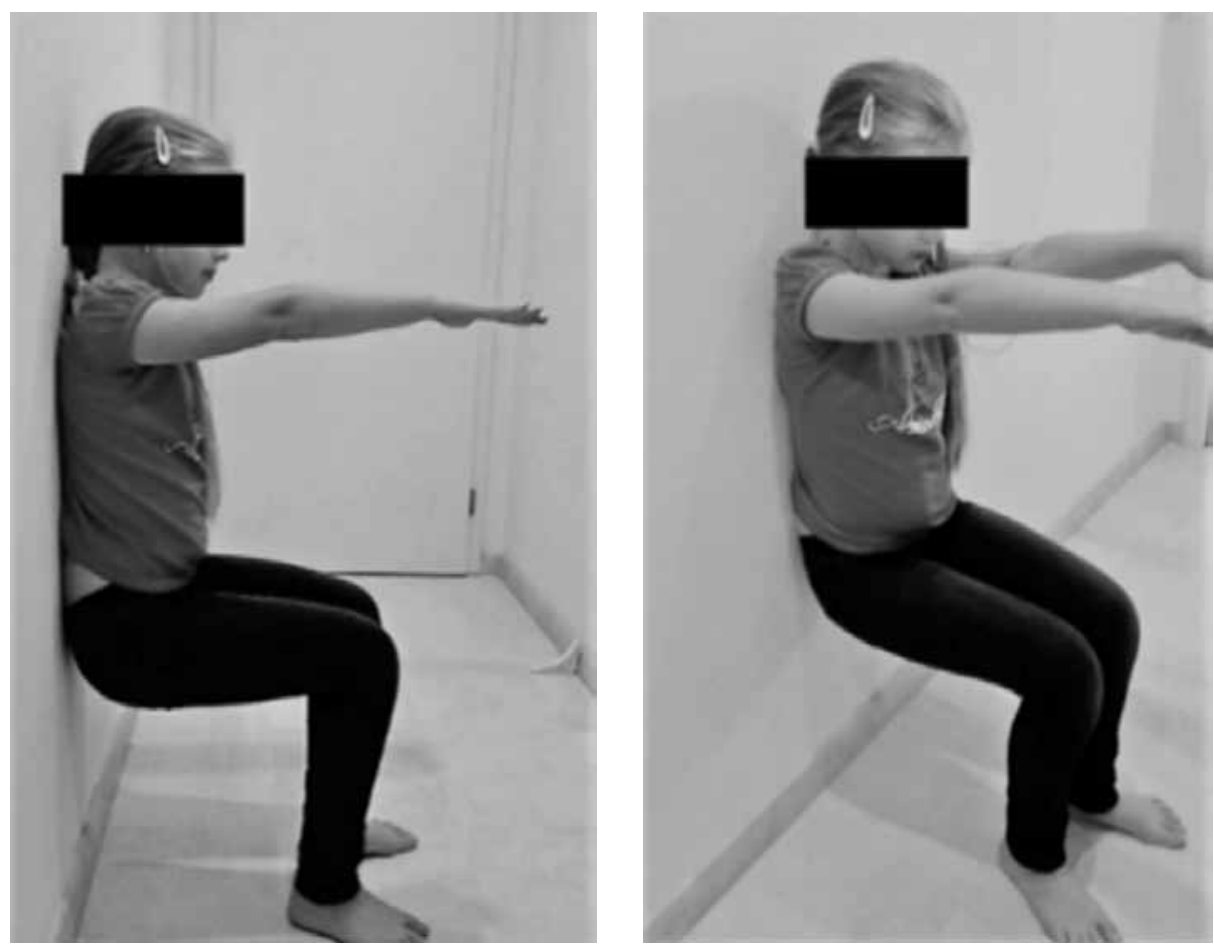
Kateřina STRAŠILOVÁ, Petr VAJDA: INFLUENCE OF SOCIAL INTERACTION IN A GROUP ON YOUNG GIRLS' PHYSICAL ..., 3-13

\section{Research Questions}

1. How does social comparison affect the performance in wall-seat test of the synchronized swimmers at the age from eight to twelve?

2. Does the social comparison have the same effect on inferior and superior members?

\section{RESULTS}

The data were tested by the Kologmo-Smirmov test and it was established that it did not come from a normal distribution. The data from both measurements were recorded and inserted into Table 1 . We can see the performance of all girls in the individual and group exercises, the differences between these two measurements and the percentage changes. The mean performance was $\mathrm{M}=108.82 \pm 57.10$ for the individual try and $\mathrm{M}=$ $271.50 \pm 218.88$ for the group one.

Other average values (median, values coming from the $2^{\text {nd }}$ and $3^{\text {rd }}$ quartile and $\mathrm{min} /$ max value) you can see from Figure 3. The influence of group interaction on the performance of synchronised swimmers was evaluated by the Cohen's $d$ which showed a high substantive dependence $(\mathrm{d}=1.1$, large effect). The Wilcoxon matched pair test was used for the data analysis. The results showed significant differences $(\mathrm{P}<0.05)$ between the performance carried out individually and the one in the group. Based on the results of both tests, we can conclude that the social interaction had a positive impact on girls' physical performance in the wall-seat test. We also evaluated the size of the motivation gain or loss for individual girls. The influence of social interaction on each girl is described in the Figure 4. The graph shows percentage changes in girls' performance between the individual and group exercises. Girls were ranked in the chart from the weakest to the strongest (rated according to their performance from individual exercises). The mean percentage change in the wall-seat position test was $+166.6 \%$ (range $-18.5 \%$ to $+616.3 \%$ ). We can see a slight trend in the graph, which suggests that inferior girls from individual exercises achieved a slightly higher positive change in performance. 
Table 1. Performance result, difference and percentage change for the wall-seat test.

\begin{tabular}{|c|c|c|c|c|}
\hline No. & $\begin{array}{l}\text { Time in individu- } \\
\text { al exercise (sec) }\end{array}$ & $\begin{array}{l}\text { Time in group } \\
\text { exercise (sec) }\end{array}$ & Difference (sec) & $\begin{array}{c}\text { Percent. Change } \\
(\%)\end{array}$ \\
\hline 1 & 32 & 34 & 2 & 6.3 \\
\hline 2 & 90 & 625 & 535 & 594.4 \\
\hline 3 & 83 & 225 & 142 & 171.1 \\
\hline 4 & 40 & 120 & 80 & 200.0 \\
\hline 5 & 83 & 171 & 88 & 106.0 \\
\hline 6 & 47 & 195 & 148 & 314.9 \\
\hline 7 & 178 & 800 & 622 & 349.4 \\
\hline 8 & 92 & 93 & 1 & 1.1 \\
\hline 9 & 62 & 121 & 59 & 95.2 \\
\hline 10 & 124 & 197 & 73 & 58.9 \\
\hline 11 & 109 & 238 & 129 & 118.3 \\
\hline 12 & 173 & 141 & -32 & -18.5 \\
\hline 13 & 102 & 337 & 235 & 230.4 \\
\hline 14 & 87 & 126 & 39 & 44.8 \\
\hline 15 & 70 & 316 & 246 & 351.4 \\
\hline 16 & 65 & 76 & 11 & 16.9 \\
\hline 17 & 330 & 411 & 81 & 24.5 \\
\hline 18 & 105 & 419 & 314 & 299.0 \\
\hline 19 & 140 & 536 & 396 & 282.9 \\
\hline 20 & 85 & 487 & 402 & 472.9 \\
\hline 21 & 86 & 91 & 5 & 5.8 \\
\hline 22 & 98 & 702 & 604 & 616.3 \\
\hline 23 & 175 & 240 & 65 & 37.1 \\
\hline 24 & 87 & 91 & 4 & 4.6 \\
\hline 25 & 109 & 108 & -1 & -0.9 \\
\hline 26 & 182 & 255 & 73 & 40.1 \\
\hline 27 & 134 & 241 & 107 & 79.9 \\
\hline 28 & 79 & 206 & 127 & 160.8 \\
\hline
\end{tabular}

Note: The girls were divided into two groups. The first one started with the individual and the other one with the group measurements. The group results are separated by a line in the tables. 
Kateřina STRAŠILOVÁ, Petr VAJDA: INFLUENCE OF SOCIAL INTERACTION IN A GROUP ON YOUNG GIRLS' PHYSICAL ..., 3-13

Fig. 3: Average difference in physical performance in wall-seat position.

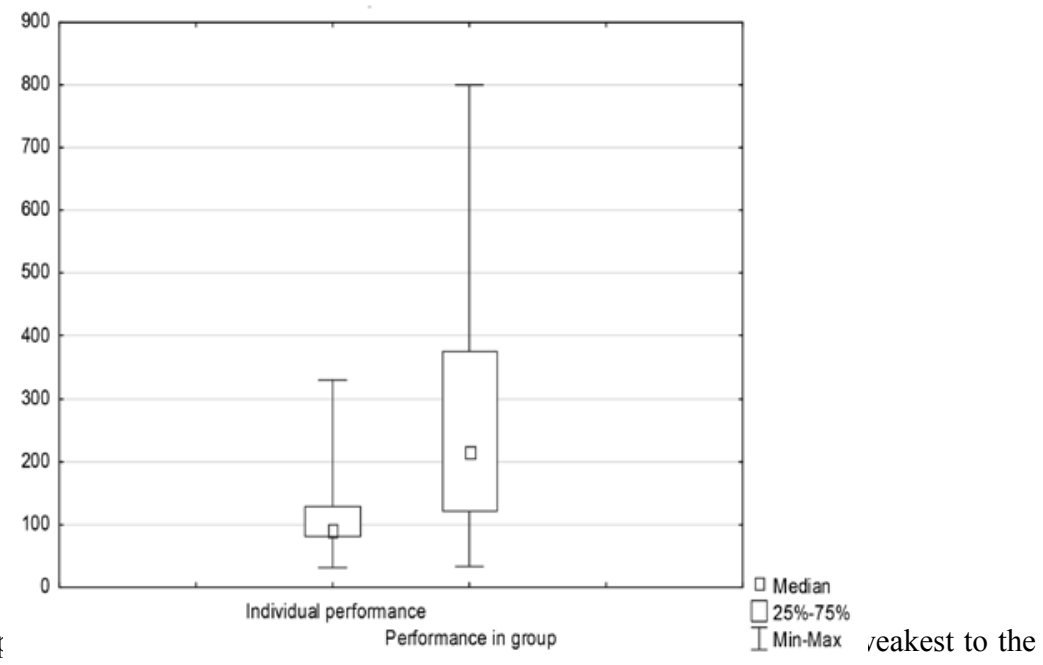

strongest one.

Fig. 4: Percentage changes in performance in individual and group tries.

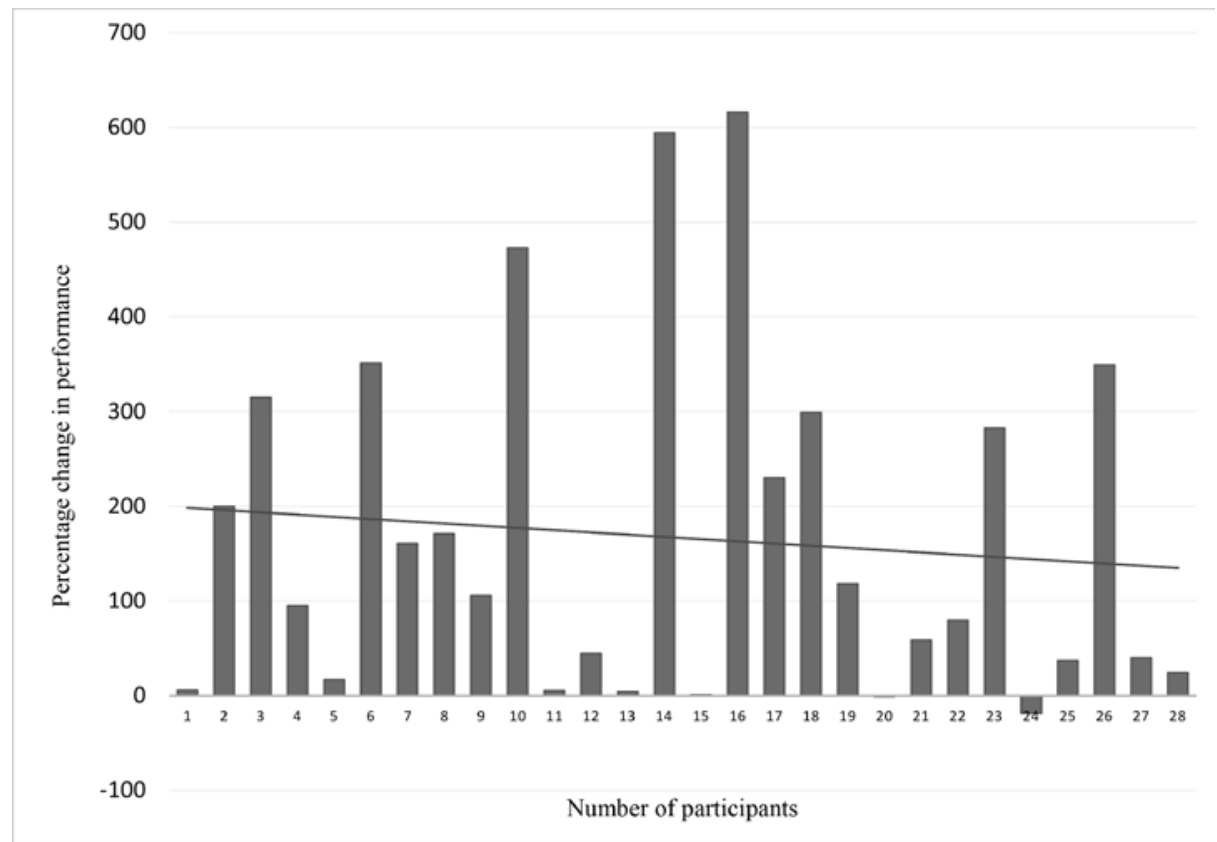




\section{DISCUSSION}

The primary aim of the study was to find out whether the group exercise (Kohler effect) could positively influence the performance of girls aged 8 to 12 . The results showed significant differences between the performance of the girls in individual and group exercises. Based on these results, we can conclude that the group exercise caused a positive performance increase for most girls, which is consistent with the results of many other studies. For example, Hertel, Kerr, and Messé (2000) investigated the influence of group condition on motor persistence task. The participants held a metal bar in stretched arms for as long as possible. The exercising time was measured in an individual and in a group condition for all the participants. In the group condition, the partners held the bar over a rope. Once the first partner touched the rope the timer was stopped and exercising was ended. The authors found out that less capable participants held the bar longer if they worked in the group. Feltz et al. (2011) empirically tested the impact of Köhler motivation gain. They found out that people who were exercising with superior partner in a series of five isometric exercises improved by $24 \%(d=0.99)$ compared to a check-up sample where people were exercising individually. Irwin et al. (2012) examined the impact of a coactive and a conjunctive task on an aerobic exercise. They described the performance increase up to $86 \%$ per coactive and even to $208 \%$ for conjunctive tasks.

We also evaluated the individual performance differences of all girls in an individual and a group try. There we can see a slightly higher impact of motivation gain on the inferior member. A similar motivation gain was described by Weber and Hertel (2007) in the coactive task. In their research, they discovered the stronger impact of social interaction due to additive and conjunctive task in women. They also suggested that the strongest gain of the Köhler effect occurs when: (a) all group members are involved in the team goal, (b) all team members care about the good team performance, (c) all group members perceive the group as a team. Furthermore, they proposed that connecting these three points could bring a particularly large enhancement in motivation. Their results showed a large effect on the physical performance due to these three points $(\mathrm{d}$ $=0.94$ ). We would like to extend our research by a comparison of these three points in accordance with Weber and Hertel in our next study.

However, the influence of the group motivation could be affected due to friendships between or among some girls. We tried to reduce the impact of friendship in the way that the experimental groups were randomly split and mixing younger and older girls. For example, the last two exercising girls in the first experimental group were from the same training group and the last two girls from the other experimental group were from different training groups. Yet all of them increased their physical performance in the group try in comparison with their individual tries. So we believe that the enhancement was caused because of the group exercising and not because of the relationships in the group. Nevertheless, it is possible that this effect will not be traceable or effective in other sport groups or in boys. Because of this reason, we would like to extend our 
research to another different group of children, for example boys, in some individual / team disciplines, games, etc.

\section{CONCLUSION}

To sum up, we established that social interaction, i.e. mutual encouragement in a group of young girls, could influence their sport performance. However, it was also found out that such social interaction / encouragement is not consistent for every girl; it was fluctuating in the sample. A small positive trend was noticed, which showed that the motivation gain was a little bit higher for the inferior group members. We believe that this effect could be important in exercises that girls do not enjoy so much and where they have to overcome a certain degree of discomfort or even pain. Not only young girls but children in general often do not understand why they should do some unpleasant activities and put their effort in them. So there is surely some extra motivation gain needed. Exercising in a training group could be used to increase the attractiveness of training in the individual sports and increase the training efforts of youth through competitions and fun. But it should be noted that group dynamics can influence the effectiveness of this result.

Nevertheless, it seems that social interaction could be beneficial for the young girls' training as well as other factors influencing a child's self-motivation, such as positive verbal motivation, constructive feedback or appraisal.

\section{REFERENCES}

Baron, R. S., \& Kerr, N. L. (2003). Group process, group decision, group action (2. ed). Buckingham: Open Univ. Press.

Carron, A. V., Hausenblas, H. A., \& Mack, D. (1996). Social influence and exercise: a meta-analysis. Journal of Sport and Exercise Psychology, 18(1), 1-16. doi: 10.1123/ jsep.18.1.1 VIEW ITEM

Dishman, R. K., \& Buckworth, J. (1996). Increasing physical activity: a quantitative synthesis. Medicine \& Science in Sports \& Exercise, 28(6), 706-719. doi: 10.1097/00005768199606000-00010 VIEW ITEM

Feltz, D. L., Kerr, N. L., \& Irwin, B. C. (2011). Buddy up: the Köhler effect applied to health games. Journal of Sport \& Exercise Psychology, 33(4), 506-526. doi: 10.1123/ jsep.33.4.506 VIEW ITEM

Heckhausen, H. (1991). Motivation and action (Tr. P. Leppmann). Berlín: Springer.

Hertel, G., Kerr, N. L., \& Messé, L. A. (2000). Motivation gains in performance groups: Paradigmatic and theoretical developments on the Köhler effect. Journal of Personality and Social Psychology, 79(4), 580-601. doi: 10.1037/0022-3514.79.4.580 VIEW ITEM

Hertel, G., Niemeyer, G., \& Clauss, A. (2008). Social indispensability or social comparison: the why and when of motivation gains of inferior group members. Journal of 
Kateřina STRAŠILOVÁ, Petr VAJDA: INFLUENCE OF SOCIAL INTERACTION IN A GROUP ON YOUNG GIRLS' PHYSICAL ..., 3-13

Applied Social Psychology, 38(5), 1329-1363. doi: 10.1111/j.1559-1816.2008.00350.x VIEW ITEM

Irwin, B. C., Scorniaenchi, J., Kerr, N. L., Eisenmann, J. C., \& Feltz, D. L. (2012). Aerobic exercise is promoted when individual performance affects the group: a test of the Köhler Motivation Gain effect. Annals of Behavioral Medicine, 44(2), 151-159. doi: 10.1007/s12160-012-9367-4 VIEW ITEM

Kerr, N. L., Messé, L. A., Seok, D.-H., Sambolec, E. J., Lount, R. B., \& Park, E. S. (2007). Psychological mechanisms underlying the Köhler Motivation Gain. Personality and Social Psychology Bulletin, 33(6), 828-841. doi: 10.1177/0146167207301020 VIEW ITEM

Mcauley, E., \& Courneya, K. S. (1993). Adherence to exercise and physical activity as health-promoting behaviors: attitudinal and self-efficacy influences. Applied and Preventive Psychology, 2(2), 65-77. doi: 10.1016/S0962-1849(05)80113-1 VIEW ITEM

Messé, L. A., Hertel, G., Kerr, N., Lount Jr, R. B., \& Park, E. S. (2002). Knowledge of partner's ability as a moderator of group motivation gains: an exploration of the Köhler discrepancy effect. Journal of Personality and Social Psychology, 82(6), 935-946. doi: 0.1037/0022-3514.82.6.935 VIEW ITEM

Osborn, K. A., Irwin, B. C., Skogsberg, N. J., \& Feltz, D. L. (2012). The Köhler effect: motivation gains and losses in real sports groups. Sport, Exercise, and Performance Psychology, 1(4), 242-253. doi: 10.1037/a0026887 VIEW ITEM

Steiner, I. D. (1972). Group process and productivity. New York: Academic Press.

Výrost, J., \& Slaměník, I. (2008). Sociální psychologie [Social psychology]. Praha: Grada.

Weber, B., \& Hertel, G. (2007). Motivation gains of inferior group members: a meta-analytical review. Journal of Personality and Social Psychology, 93(6), 973-993. doi: 10.1037/0022-3514.93.6.973 VIEW ITEM 